University of Nebraska - Lincoln

DigitalCommons@University of Nebraska - Lincoln

Faculty Papers and Publications in Animal

Science

Animal Science Department

1987

\title{
Influence of Picolinic Acid on the Uptake of Zinc-Amino Acid Complexes by the Everted Rat Gut
}

\author{
D. A. Hill \\ Roman L. Hruska USMARC \\ E. R. Peo, Jr. \\ University of Nebraska-Lincoln
}

A. J. Lewis

University of Nebraska-Lincoln, alewis2@unl.edu

Follow this and additional works at: https://digitalcommons.unl.edu/animalscifacpub

Part of the Animal Sciences Commons

Hill, D. A.; Peo, Jr., E. R.; and Lewis, A. J., "Influence of Picolinic Acid on the Uptake of Zinc-Amino Acid Complexes by the Everted Rat Gut" (1987). Faculty Papers and Publications in Animal Science. 684. https://digitalcommons.unl.edu/animalscifacpub/684

This Article is brought to you for free and open access by the Animal Science Department at DigitalCommons@University of Nebraska - Lincoln. It has been accepted for inclusion in Faculty Papers and Publications in Animal Science by an authorized administrator of DigitalCommons@University of Nebraska - Lincoln. 


\title{
INFLUENCE OF PICOLINIC ACID ON THE UPTAKE OF ${ }^{65}$ ZINC-AMINO ACID COMPLEXES BY THE EVERTED RAT GUT ${ }^{1,2,3}$
}

\author{
D. A. Hill ${ }^{4}$, E. R. Peo, Jr. ${ }^{5}$ and A. J. Lewis \\ University of Nebraska ${ }^{6}$ \\ Lincoln 68583-0908
}

\begin{abstract}
Three hundred fifty rats were used in three experiments to: 1) validate the everted gut procedure as an in vitro technique for estimating $Z_{n}$ absorption, 2) determine the effect of increasing ratios of picolinic acid (PA) to $\mathrm{Zn}$ on $\mathrm{Zn}$ absorption and 3 ) determine the effect of $\mathrm{PA}$ on $\mathrm{ab}$ sorption of $\mathrm{Zn}$ and amino acid complexes at $\mathrm{pH} 6,7$ and 8 . In the first experiment the time delay between tissue collection with subsequent storage in ice-cold saline and start of tissue incubation was $0,10,20$ or $30 \mathrm{~min}$. A linear decrease was observed for ${ }^{65} \mathrm{Zn}$ uptake with increasing delay time. Lysine absorption was not affected by delay time. In the second experiment, molar ratios of PA: $\mathrm{Zn}$ of $0, .5,1.0,1.5,2.0$ and 2.5 with $\mathrm{Zn}$ held constant were evaluated. A linear decrease in ${ }^{65} \mathrm{Zn}$ absorption from ${ }^{65} \mathrm{ZnCl}_{2}$ occurred as the molar ratio of $\mathrm{PA}$ to $\mathrm{Zn}$ increased. In the third experiment, 0 and 5 molar ratios of $P A$ to a constant $\mathrm{Zn}$ level were evaluated using ${ }^{65} \mathrm{ZnCl}_{2}$,

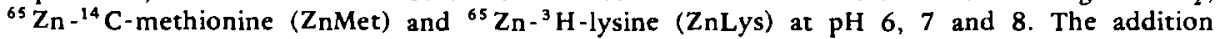
of PA decreased $\mathrm{Zn}_{n}$ absorption regardless of $\mathrm{Z}_{n}$ source. The data suggest that the $\mathrm{Z}_{n}$ sources used were of similar biological value. The data do not support the theory that PA facilitates $Z_{n}$ absorption.

(Key Words: Rats, Zinc, Methionine, Lysine, Picolinic Acid.)
\end{abstract}

\section{Introduction}

Acrodermatitis enteropathica (AE), a form of $\mathrm{Zn}$ deficiency (Moynahan, 1974) and malabsorption in humans, has been treated with diiodohydroxyquin (a chelating agent) since 1953 (Dillaha et al., 1953). Acrodermatitis enteropathica is observed when infants who have been receiving human breast milk are weaned to cow milk or soy-based formulas. This suggests that human milk contains factor(s) that enhance $\mathrm{Zn}$ absorption and(or) that cow milk and soy formulas contain factors that depress $\mathrm{Zn}$ absorption.

\footnotetext{
${ }^{1}$ Published as paper no. 8212, Journal Series, Nebraska Agr. Res. Div.

${ }^{2}$ Radio-labeled zinc-amino acid complexes donated by ZINPRO Corp., Chaska, MN 55318.

${ }^{3}$ The technical assistance of $R$. M. Hill, Dept. of Agr. Biochem. and Joy Kovar, Dept. of Anim. Sci. is gratefully acknowledged; appreciation is expressed to Diana J. Smith for manuscript preparation.

${ }^{4}$ Current address: Roman L. Hruska USMARC, Clay Center, NE 68933.

${ }^{5}$ To whom reprint requests should be addressed.

${ }^{6}$ Dept. of Anim. Sci.

${ }^{7}$ Wayne LAB-BLOX, Div. of Allied Mills, Chicago, IL 60606.

Received December 22, 1986.

Accepted March 11, 1987.
}

Hahn and Evans (1973) detected a low molecular weight $\mathrm{Zn}$-binding ligand $(\mathrm{ZnBl})$ in rat intestinal mucosal cells and in pancreatric secretions in the dog (Evans et al., 1975). This low molecular weight $\mathrm{ZnBL}$ was isolated (Evans and Johnson, 1979) and identified (Evans and Johnson, 1980) as picolinic acid (PA), a metabolite of tryptophan. The authors suggested that the PA in human milk and pancreatic secretions facilitates $\mathrm{Zn}_{n}$ absorption from the intestine. If $\mathrm{PA}$ chelates $\mathrm{Zn}$ and facilitates its absorption, then it may do so by: 1) maintaining dietary $\mathrm{Zn}$ in a soluble form to allow maximum opportunity for contact with intestinal mucosa, or 2 ) by being absorbed into the mucosal cell as the $\mathrm{Zn}$ $\mathrm{ZnBL}$ complex. If the $\mathrm{Zn}-\mathrm{PA}$ complex does, in fact, facilitate $\mathrm{Zn}$ absorption then presentation of this complex to intestinal tissue would be expected to result in greater and(or) more rapid tissue uptake of $\mathrm{Zn}$. The following experiments were conducted to test this hypothesis.

\section{Materials and Methods}

Three hundred fifty male Sprague-Dawley rats were fed a commercial rat $\operatorname{diet}^{7}$ containing $75.8 \mathrm{ppm} \mathrm{Zn}$ (by analysis) for at least $7 \mathrm{~d}$, fasted overnight and then killed by stun- 
TABLE 1. EXPERIMENTAL SOLUTIONS

\begin{tabular}{lr}
\hline Item & Concentration \\
\hline Isotonic saline solution & \\
$\mathrm{NaCl}$ & $8.5322 \mathrm{~g} / \mathrm{liter}$ \\
$\mathrm{KCl}$ & $.2982 \mathrm{~g} / \mathrm{liter}$ \\
to 1 litter with distilled deionized water & \\
Saline - buffer solution & \\
$\mathrm{NaCl}$ & \\
$\mathrm{TRIS}$ & \\
$\mathrm{CaCl}_{2}: 2 \mathrm{H}_{2} \mathrm{O}$ & $8.1816 \mathrm{~g} / \mathrm{liter}$ \\
$\mathrm{MgCl}_{2}: 6 \mathrm{H}_{2} \mathrm{O}$ & $.9692 \mathrm{~g} /$ liter \\
$\mathrm{D}(+)$ mannose & $.0147 \mathrm{~g} / \mathrm{liter}$ \\
& $.2170 \mathrm{~g} /$ liter \\
\hline
\end{tabular}

${ }^{a}$ To 1 liter with distilled deionized water.

$\mathrm{b}_{\mathrm{pH}}$ adjusted with $1 \mathrm{~N}$ HCl.

${ }^{c_{\text {Pre-oxygenated for }}} 60 \mathrm{~min}$ before use by constant bubbling of $\mathrm{O}_{2}$ into solution.

ning and exsanguination. A duodenal sac was prepared for the everted gut by previously defined procedures (Manis and Schachter, 1962). Everted gut sections were held in an ice-cold isotonic saline solution (table 1) until just prior to the start of incubation. One-half milliliter of pre-oxygenated isotonic saline-buffer solution (table 1) was put into the gut sac and the sac was tied. The gut sac was placed into a test tube containing $10 \mathrm{ml}$ of the same saline-buffer solution used inside the gut sac. ${ }^{65} \mathrm{Zn}$ was then added to the buffer in the test tubes. The incubation period was $60 \mathrm{~min}$ at $37 \mathrm{C}$ in a shaking water bath (90 oscillations/min). Picolinic acid, when used, was added to the outer buffer containing the ${ }^{65} \mathrm{Zn}$. After 60 min of incubation, the gut sacs were removed from the isotopic-labeled buffer solution, carefully opened, and the inside of the sac (serosal side) was gently rinsed with $3 \mathrm{ml}$ distilled water. The concentration of isotope was then determined in contents inside the sac with the rinse, the gut tissue itself, and the labeled buffer solution. Activity of ${ }^{65} \mathrm{Zn}$ was determined using a deep-well gamma counter. The tissue was then solubilized for analysis of ${ }^{14} \mathrm{C}$-methionine or ${ }^{3} \mathrm{H}$-lysine (TS-1 tissue solubilizer) ${ }^{8}$ in liquid scintillation cocktail (Biocount scintillation cocktail $)^{8}$. Nutrient absorption was considered to be the activity (cpm for ${ }^{65} \mathrm{Zn}$ and $\mathrm{dpm}$

\footnotetext{
${ }^{8}$ Research Products International, Mt. Prospect, IL 60056 .

${ }^{9}$ Perkin-Elmer Model 303, Norwalk, CT 06856.

${ }^{10}$ New England Nuclear, Boston, MA 02118.
}

for ${ }^{14} \mathrm{C}$ and ${ }^{3} \mathrm{H}$ ) inside of the gut sac plus the activity in the gut wall itself divided by the sum of the activity found in all three fractions.

Zinc analysis of the diet sample was accomplished by dry-ashing duplicate $5-\mathrm{g}$ samples at $550 \mathrm{C}$ for $8 \mathrm{~h}$. The ash was then extracted twice with $10 \mathrm{ml}$ hot $6 \mathrm{~N} \mathrm{HCl}$ and twice with hot distilled deionized water. The extract was filtered and analyzed by atomic absorption spectrophotometry ${ }^{9}$ as described by Perkin-Elmer (1971).

In the first experiment the tissue was stored in ice-cold isotonic saline solution for 0 , 10,20 or $30 \mathrm{~min}$ to evaluate the effect of delay time between tissue collection and start of tissue incubation on $\mathrm{Zn}$ absorption. Forty-eight rats weighing $266 \pm 22 \mathrm{~g}$ were used in the experiment. A ${ }^{65} \mathrm{Zn}_{\mathbf{n}}{ }^{3} \mathrm{H}$-lysine complex $(.8 \mu \mathrm{M} \mathrm{Zn}$ and $.8 \mu \mathrm{M}$ lysine/intestinal segment) was used at $\mathrm{pH} 7.4$ to evaluate $\mathrm{Zn}$ and lysine absorption uptake from everted gut loops at normal body $\mathrm{pH}$.

In the second experiment the effect of molar ratios of $\mathrm{PA}$ to $\mathrm{Zn}(.8 \mu \mathrm{M})$ from ${ }^{65} \mathrm{ZnCl}_{2}{ }^{10}$ of $0, .5,1.0,1.5,2.0$ or 2.5 on $\mathrm{Zn}$ absorption at $\mathrm{pH} 8$, a $\mathrm{pH}$ level similar to pancreatic secretions was determined. Seventy-two rats with an average weight of $198 \pm 34 \mathrm{~g}$ were used.

In the third experiment a $3 \times 2 \times 3$ factorial arrangement of treatments was used with three $\mathrm{Zn}$ sources, ${ }^{65} \mathrm{ZnCl}_{2},{ }^{65} \mathrm{Zn}^{14}{ }^{14} \mathrm{C}$ methionine (ZnMet) and ${ }^{65} \mathrm{Zn}^{-3} \mathrm{H}$-lysine (ZnLys), 0 or 5 molar ratio of PA to $.8 \mu \mathrm{M}$ $\mathrm{Zn}$, and $\mathrm{pH}$ levels of 6,7 or 8 . The $\mathrm{pH}$ levels were considered to be similar to those found 
TABLE 2. EFFECT OF DELAY TIME BETWEEN

TISSUE COLLECTION AND START OF INCUBATION ON ${ }^{65} \mathrm{Zn}_{\mathrm{n}}$ ABSORPTION (PERCENT OF ZN DOSE FROM ${ }^{65} \mathrm{Zn}^{-3} \mathrm{H}$-LYSINE COMPLEX)

\begin{tabular}{ccrcc} 
& \multicolumn{2}{c}{ Absorption } & & \\
\cline { 2 - 5 } Delay, min & Serosal $^{2}$ & Gut $^{\mathrm{b}}$ & Total $^{\mathrm{c}}$ & $\mathrm{N}^{\mathrm{d}}$ \\
\hline 0 & 5.34 & 24.38 & 29.72 & 10 \\
10 & 5.27 & 21.05 & 26.32 & 13 \\
20 & 5.50 & 16.07 & 21.57 & 13 \\
30 & 4.90 & 20.19 & 25.09 & 12 \\
$\mathrm{SE}$ & .48 & 1.22 & 1.33 & \\
\hline
\end{tabular}

${ }^{a}$ No differences ( $\left.P>.58\right)$.

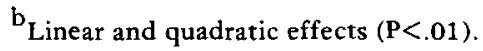

${ }^{\mathrm{c}}$ Values are the sum of the serosal and gut analysis; Linear effect $(P<.01)$, quadratic effect $(P<.02)$.

$\mathbf{d}_{\mathbf{N}}=$ number of observations per treatment.

in the small intestine and pancreatic secretions. Absorption of ${ }^{65} \mathrm{Zn}$ and amino acids was determined as described previously. Average weight of the 230 rats used in this experiment was $271 \pm 101 \mathrm{~g}$.

The response criteria were analyzed by orthogonal contrasts as described by Steel and Torrie (1980) and calculated after SAS (1979). Specific statistical components tested were: Exp. 1, the regression of time; Exp. 2, the regression of the effect of added PA on $\mathrm{Zn}$ absorption; and Exp. 3, the regression components of levels of $\mathrm{pH}$, the main effect of PA, inorganic vs organic $\mathrm{Zn}, \mathrm{ZnMet} v \mathrm{~s}$ ZnLys and all possible interactions.

TABLE 3. EFFECT OF DELAY TIME BETWEEN TISSUE COLLECTION AND START OF INCUBATION ON LYSINE UPTAKE (PERCENT OF ${ }^{3} \mathrm{H}$-LYSINE DOSE)

\begin{tabular}{ccccc}
\hline & \multicolumn{2}{c}{ Absorption $^{\mathrm{a}}$} & & \\
\cline { 2 - 4 } Delay, min & Serosal & Gut & Total $^{\mathrm{b}}$ & $\mathrm{N}^{\mathrm{c}}$ \\
\hline 0 & 12.76 & 7.48 & 20.24 & 10 \\
10 & 14.44 & 7.45 & 21.89 & 13 \\
20 & 11.57 & 7.41 & 18.98 & 13 \\
30 & 11.34 & $\mathbf{8 . 1 0}$ & 19.44 & 12 \\
SE & 2.86 & 1.74 & 4.45 &
\end{tabular}

${ }^{a}$ No differences $(P>.52)$.

${ }^{b}$ Sum of serosal and gut dose.

$c_{N}=$ number of observations per treatment.

\section{Results and Discussion}

Results of Exp. 1 are presented in table 2 as percentage of dose for ${ }^{65} \mathrm{Zn}$ uptake. A linear $(\mathbf{P}<.01)$ and quadratic $(\mathbf{P}<.02)$ decrease in $\mathrm{Zn}$ absorption was observed for total ${ }^{65} \mathrm{Zn}$ uptake into gut tissue as delay time increased. The percentage of ${ }^{65} \mathrm{Zn}$ recovered on the serosal side of the sac was not affected by delay time. Lysine uptake was not affected (table 3) either to the serosal side of the gut sac or into the gut tissue. Lysine uptake was considerably more variable across treatments than $\mathrm{Zn}$ uptake. Lysine absorption to the serosal side averaged $12.5 \%$, while total lysine absorption averaged $20.1 \%$. Zinc absorption to the serosal side of the gut sac averaged $5.3 \%$ of the test dose, while total $\mathrm{Zn}_{\mathrm{n}} \mathrm{ab}$ sorption ranged from 21.6 to $29.7 \%$. The $\mathrm{Zn}$ absorption data indicate that time between sacrifice and start of incubation should be minimized.

The results of increasing the molar ratio between PA and $\mathrm{Zn} \mathrm{(Exp.} \mathrm{2)} \mathrm{are} \mathrm{presented}$ in table 4 . The addition of $P A$ decreased the absorption of ${ }^{65} \mathrm{Zn}$ from ${ }^{65} \mathrm{ZnCl}_{2}$ at $\mathrm{pH}$ 8. There was a linear decrease $(\mathrm{P}<.01)$ in $\mathrm{Zn}$ absorption as the $\mathrm{PA}$ molar ratio was increased. The ability of PA to chelate $\mathrm{Zn}$ is clear (Evans and Johnson, 1980), but a physiological role for PA is not evident from this experiment because graded levels of PA depressed $\mathrm{Zn}$ absorption. A quadratic effect $(\mathrm{P}<.01)$ of $\mathrm{PA}$ on total $\mathrm{Zn}$ absorption and

TABLE 4. EFFECT OF INCREASING MOLAR RATIO OF PICOLINIC ACID ON ABSORPTION OF ${ }^{65} \mathrm{Zn}$ AT pH 8.0 (PERCENT OF ${ }^{65} \mathrm{ZnCl}_{2}$ DOSE)

\begin{tabular}{crrrr}
\hline & \multicolumn{2}{c}{ Absorption } & & \\
\cline { 2 - 5 } PA molar ratio & Serosal $^{\mathrm{a}}$ & Gut $^{\mathrm{b}}$ & Total $^{\mathrm{c}}$ & $\mathrm{N}^{\mathrm{d}}$ \\
\hline 0 & 3.18 & 28.68 & 31.86 & 12 \\
.5 & 2.53 & 24.61 & 27.14 & 12 \\
1.0 & 2.65 & 20.70 & 23.35 & 12 \\
1.5 & 2.50 & 19.86 & 22.36 & 12 \\
2.0 & 2.40 & 17.27 & 19.67 & 12 \\
2.5 & 2.26 & 16.66 & 18.92 & 11 \\
SE & .21 & .82 & .92 & \\
\hline
\end{tabular}

${ }^{a}$ Linear effect $(\mathrm{P}<.01)$.

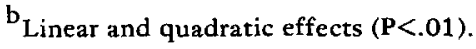

$c_{\text {Linear }}$ and quadratic effects $(\mathbf{P}<.01)$; sum of serosal and gut dose.

$\mathrm{d}_{\mathrm{N}}=$ number of observations per treatment. 
$\mathrm{Zn}$ absorption into the gut tissue was detected and is believed to be an indication that the first increments of PA addition resulted in the greatest percentage decrease in $\mathrm{Zn}$ absorption.

The effects of $\mathrm{Zn}$ source, $\mathrm{pH}$ and addition of PA on ${ }^{65} \mathrm{Zn}$ absorption are presented in table 5. A depression in ${ }^{65} \mathrm{Zn}$ absorption with the addition of PA was evident for total ${ }^{65} \mathrm{Zn}$ absorption and ${ }^{65} \mathrm{Zn}$ absorption to the serosa. The addition of a $5 \mathrm{M} \mathrm{PA}$ ratio to $\mathrm{Zn}$ reduced total ${ }^{65} \mathrm{Zn}$ absorption to $53 \%$ and serosal absorption to $60 \%$ of absorption levels without PA. However, absorption of ${ }^{65} \mathrm{Zn}$ from the three sources responded differently to the addition of PA at the three $\mathrm{pHs}$, which resulted in $\mathrm{pH} \times \mathbf{P A}$ interactions $(P<.02)$ for ${ }^{65} \mathrm{Zn}$ absorption in the gut tissue and for total absorption. Zinc from ${ }^{65} \mathrm{ZnCl}_{2}$ was absorbed into the gut tissue more readily than were the organic $\mathrm{Zn}$ sources $(\mathrm{P}<.04)$. There was a similar trend $(P<.09)$ for total $\mathrm{Zn}$ uptake.

Absorption of the radiolabeled amino acids are presented in table 6. Absorption of amino acids into the gut tissue resulted in a $\mathrm{pH} \times \mathbf{P A}$ interaction caused by the increased lysine absorption in the presence of PA at $\mathrm{pH} 7$. The same response also resulted in a $\mathrm{Zn}$ source $x \mathrm{pH}$ interaction for amino acid uptake to the serosal side of the gut sac and total amino acid absorption. Across both PA treatments, there was more lysine ( $14.2 \%$ of dose) found on the serosal side of the gut sac than methionine ( $5.1 \%$ of dose).

Although the amino acid uptake is characterized by much higher variability than $\mathbf{Z n}$ uptake, the $\mathrm{Zn}$-amino acid complexes do not appear to be absorbed intact. If the $\mathrm{Zn}$ amino acid complexes were absorbed intact, similar ranges between percentage of dose of $\mathrm{Zn}$ and complexed amino acid would be expected.

Methionine is absorbed at a faster rate than lysine in vivo (Kidder and Manners, 1978). The mechanisms of absorption of neutral amino acids (including methionine) and basic amino acids (including lysine) are energy-dependent (Davenport, 1982). The buffers were oxygenated prior to, but not

TABLE 5. ABSORPTION OF ${ }^{65} \mathrm{Zn}$ (PERCENT OF DOSE) AS AFFECTED BY SOURCE, pH AND ADDED PICOLINIC ACID (PA)

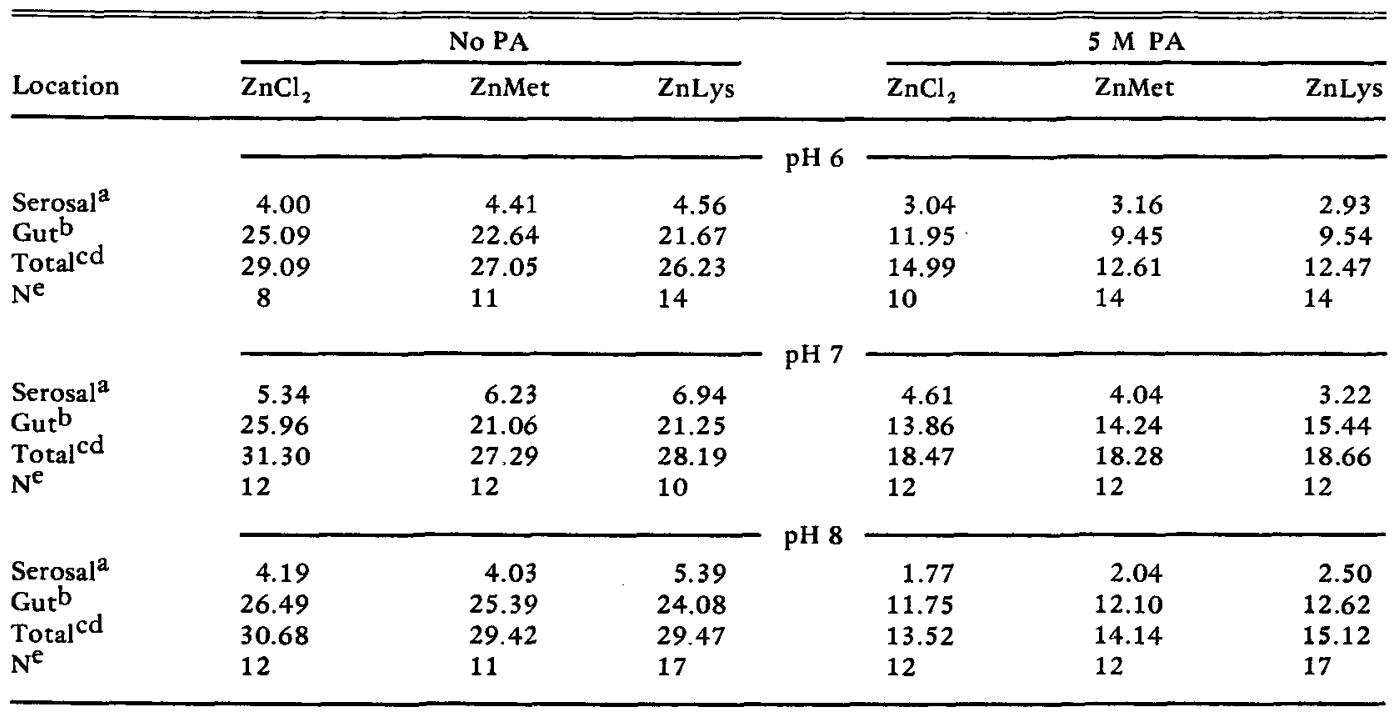

${ }^{\mathrm{a}}$ Serosal side: no PA vs PA, pH quadratic, pH quadratic $X \mathrm{PA}$ interaction $(\mathrm{P}<.01)$; $\mathrm{pH}$ linear $(\mathrm{P}<.03)$.

${ }^{\mathrm{b}} \mathrm{Gut}$ : no PA vs PA $(\mathrm{P}<.01)$; inorganic $\mathrm{Zn}$ vs organic $\mathrm{Zn}(\mathrm{P}<.04)$; $\mathrm{pH}$ linear $(\mathrm{P}<.03)$; pH quadratic $\times$ PA interaction $(\mathrm{P}<.01)$.

Total: Sum of serosal and gut dose; no PA vs $\mathrm{PA}(\mathrm{P}<.01)$; $\mathrm{pH}$ quadratic $(\mathrm{P}<.01)$.

$\mathrm{d}_{\mathrm{SE}}$ : serosal side, 1.52; gut absorption, .49; total absorption, 1.57 .

$\mathrm{e}_{\mathrm{N}}=$ number of observations per treatment. 
TABLE 6. ABSORPTION OF RADIOLABELED AMINO ACIDS (PERCENT OF DOSE) AS AFFECTED BY $Z$ n SOURCE, pH AND ADDED PICOLINIC ACID (PA)

\begin{tabular}{|c|c|c|c|c|}
\hline \multirow[b]{2}{*}{ Location } & \multicolumn{2}{|c|}{ No PA } & \multicolumn{2}{|c|}{5 M PA } \\
\hline & $\mathrm{ZnMET}$ & ZnLys & ZnMET & ZnLys \\
\hline $\begin{array}{l}\text { Serosal } \\
\text { Gut }^{\mathrm{a}} \\
\text { Total } \\
\text { Ne }\end{array}$ & $\begin{array}{l}6.19 \\
10.27 \\
16.46 \\
13\end{array}$ & $\begin{array}{l}19.58 \\
15.64 \\
35.22 \\
14\end{array}$ & $\begin{array}{r}4.90 \\
8.15 \\
13.05 \\
13\end{array}$ & $\begin{array}{l}21.55 \\
10.06 \\
31.61 \\
13\end{array}$ \\
\hline $\begin{array}{l}\text { Serosal }^{\mathrm{a}} \\
\text { Gut }^{\mathrm{b}} \\
\text { Total }^{\text {cd }} \\
\mathrm{N}^{\mathrm{e}}\end{array}$ & $\begin{array}{l}8.17 \\
10.93 \\
19.10 \\
10\end{array}$ & $\begin{array}{c}8.62 \\
8.38 \\
17.00 \\
9\end{array}$ & $\begin{array}{l}5.71 \\
8.55 \\
14.26 \\
10\end{array}$ & $\begin{array}{r}18.01 \\
8.43 \\
26.44 \\
11\end{array}$ \\
\hline $\begin{array}{l}\text { Serosal } \\
\text { Gut }^{\mathrm{b}} \\
\text { Total }^{\mathrm{cd}} \\
\mathrm{N}^{\mathrm{e}}\end{array}$ & $\begin{array}{l}3.25 \\
5.72 \\
8.97 \\
9\end{array}$ & $\begin{array}{r}9.47 \\
7.03 \\
16.50 \\
11\end{array}$ & $\begin{array}{l}2.24 \\
4.55 \\
6.79 \\
9\end{array}$ & $\begin{array}{r}7.97 \\
6.47 \\
14.44 \\
16\end{array}$ \\
\hline
\end{tabular}

${ }^{a}$ Serosal side: Met vs Lys, pH linear $(P<.01)$; (Met vs Lys) $\times \mathrm{pH}$ linear $\mathbf{P A}$ interaction $(\mathrm{P}<.01)$.

${ }^{\mathrm{b}}$ Gut: $\mathrm{pH}$ linear $(\mathrm{P}<.01)$; no PA vs PA $(\mathrm{P}<.05)$.

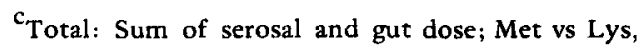
$\mathrm{pH}$ linear $(\mathbf{P}<.01)$; (Met vs Lys) $X \mathrm{pH}$ linear interaction $(\mathbf{P}<.04)$.

$\mathrm{d}_{\mathrm{SE}}$ : serosal side, 2.43; gut absorption, 1.62; total absorption, 3.62.

${ }^{e} N=$ number of observations per treatment.

during the $60-\mathrm{min}$ incubation. The neutral amino acid absorption mechanisms may be more prone to oxygen limitation than basic amino acid absorption systems.

Currently there is general agreement among researchers regarding the existence of (a) low molecular weight $\mathrm{Zn}$-binding ligand(s) in human milk, but its(their) identity(ies) remain controversial (Song and Adham, 1978; Cousins and Smith, 1980; Evans, 1980; Hurley and Lonnerdal, 1982; Robello et al., 1982). If the ligand found in milk facilitates $\mathrm{Zn}$ absorption, then it is reasonable to expect that presentation of the ligand to intestinal tissue would enhance $\mathrm{Zn}$ absorption as well. Oestreicher and Cousins (1982) found that picolinate did not enhance $\mathrm{Zn}$ absorption in isolated, vascularly perfused rat intestines. Menard and Cousins (1983) used rat intestine brush border membrane vesicles and found $\mathrm{Zn}$ uptake to be depressed by picolinate. However, Seal and Heaton (1983), used everted rat duodenal sacs with $\mathrm{ZnCl}_{2}$ as a control, and found a fourfold increase in $\mathrm{Zn}$ uptake when picolinate was added to a system using a 30 -fold higher concentration of zinc than was used in this study and a 50:1 ratio of $P A: Z n$. Others have shown that $\mathrm{Zn}$ absorption is not improved by the addition of picolinic acid in cattle (Flagstad, 1981), sheep (Ivan and Lamand, 1981) or pigs (Hill et al., 1986).

The data presented indicate that the $\mathrm{Zn}$ sources used in these experiments are of similar biological value, and do not support the theory that picolinic acid enhances $\mathrm{Zn}_{\mathrm{n}}$ absorption.

\section{Literature Cited}

Cousins, R. J. and K. T. Smith. 1980. Zinc-binding properties of bovine and human milk in vitro: Influence of changes in zinc content. Amer. J. Clin. Nutr. 33:1083.

Davenport, H. W. 1982. Intestinal digestion and absorption of protein. In: Physiology of the Digestive Tract - An Introductory Text (5th Ed.) pp 205-210. Year Book Medical Publishers, Inc., Chicago, IL.

Dillaha, C. J., A. L. Lorincz and O. R. Aavik. 1953 Acrodermatitis enteropathica - A review of the literature and report of a case successfully treated with diodoquin. J. Amer. Med. Assoc. 152:509.

Evans, G. W. 1980. Normal and abnormal zinc absorption in man and animals: The tryptophan connection. Nutr. Rev. 38:137.

Evans, G. W., C. I. Grace and H. J. Votava. 1975. A proposed mechanism for zinc absorption in the rat. Amer. J. Physiol. 228:501.

Evans, G. W. and P. E. Johnson. 1979. Purification and characterization of a zinc-binding ligand in human milk. Fed. Proc. 38 (3 part 1):703 (Abstr.).

Evans, G. W. and P. E. Johnson. 1980. Characterization and quantitation of zinc-binding ligand in human milk. Pediatr. Res. 14:876.

Flagstad, T. 1981. Zinc absorption in cattle with a dietary picolinic acid supplement. J. Nutr. 111:1996.

Hahn, C. J. and G. W. Evans. .1973. Identification of a low molecular weight ${ }^{65} \mathrm{Zn}$ complex in rat intestine. Proc. Soc. Exp. Biol. Med. 144: 793.

Hill, D. A., E. R. Peo, Jr., A. J. Lewis and J. D. Crenshaw. 1986. Zinc-amino acid complexes for swine. J. Anim. Sci. 63:121.

Hurley, L. S. and B. Lonnerdal. 1982. Zinc binding in human milk: Citrate versus picolinate. Nutr. Rev. 40:65.

Ivan, $M$. and $M$. Lamand. 1981. The influence of intraruminal and intraduodenal infusion of picolinic acid on metabolism of ${ }^{65} \mathrm{Zn}$ in sheep. Ann. Rech. Vet. 12:337.

Kidder, D. E. and M. J. Manners. 1978. Digestion of protein. In: Digestion in the Pig. pp 150- 
171. Scientechnica, Bristol.

Manis, J. G. and D. Schachter. 1962. Active transport of iron by intestine: Features of the two-step mechanism. Amer. J. Physiol. 203:73.

Menard, M. P. and R. J. Cousins. 1983. Effect of citrate, glutathione and picolinate on zinc transport by brush border membrane vesicles from rat intestine. J. Nutr. 113:1653.

Moynahan, E. J. 1974. Acrodermatitis enteropathica: A lethal inherited human zinc-deficiency disorder. Lancet 2:399.

Oestreicher, P. and R. J. Cousins. 1982. Influence of intraluminal constitutents by zinc absorption by isolated, vascularly perfused rat intestine. J. Nutr. 112:1978.

Perkin-Elmer. 1971. Analytical methods for atomic absorption spectrophotometry. Perkin-Elmer,
Norwalk, CT.

Rebello, T., B. Lonnerdal and L. S. Hurley. 1982. Picolinic acid in milk, pancreatic juice and intestine: Inadequate for role in zinc absorption. Amer. J. Clin. Nutr. 35:1.

SAS. 1979. SAS User's Guide. Statistical Analysis System Institute, Inc., Cary, NC.

Seal, C. J. and F. W. Heaton. 1983. Chemical factors affecting the intestinal absorption of zinc in vitro and in vivo. Brit. J. Nutr. 40:317.

Song, M. K. and N. F. Adham. 1978. Role of prostaglandin $E_{2}$ in zinc absorption in the rat. Amer. J. Physiol. 234:E99.

Steel, R.G.D. and J. H. Torrie. 1980. Principles and Procedures of Statistics - A Biometrical Approach (2nd Ed.). McGraw-Hill Book Co., New York, NY. 